\title{
Mechanism of State Tax Regulation in the Global Economy
}

Adigamova Farida F.

Kazan Federal University, Institute of Management, Economics and Finance, Kazan, 420008, Russia

Safiullin Marat A.

Kazan Federal University, Institute of Management, Economics and Finance, Kazan, 420008, Russia

Tufetulov Aidar M.

Kazan Federal University, Institute of Management, Economics and Finance, Kazan, 420008, Russia

Email : ajdar-t@yandex.ru

\section{Doi:10.5901/mjss.2014.v5n24p193}

\section{Abstract}

The article offers a step-by-step model for the formation of a single interstate tax regulation in existing cross-national alliances; identifies and systematizes impacts on interstate tax regulation; proposes measures of competitiveness for existing alliances. In this paper, the authors point out that one can observe the convergence of tax systems in the context of growing international economic integration, which is expressed in the approximation of the levels of taxation in the economies of individual countries. It is the harmonization of tax legislation that reflects this process. In this paper the authors draw conclusions about the impact of variations in VAT rates on macroeconomic indicators in the event of possible harmonization of tax legislation: the case of the Russian Federation, Kazakhstan and Kyrgyzstan.

Keywords: Economy, globalization, integration, harmonization, regulation, transformation, taxes, budget, competition, risks, experience, factors, rate, trends, revenues, results.

\section{Introduction}

Under the conditions of activation in the processes of internationalization and integration of the world economy, there is an increasing globalization of national economies, which should lead to a reduction of the state influence on the economy on the one hand, and there are new forms of the world economy, where government regulation has to adapt to the new conditions, on the other hand In the past two decades, the dualistic nature of the state's role in regulating the global economy can be particularly observed on the example of the tax regulation.

Currently, the most relevant is the question of the development of uniform international standards to regulate economic activity, which, however, will have fundamentally different implications for different groups of countries and will be associated with an increase in conflicts among them, as well as within individual groups (Kuptsova, 2004). That is why in recent years due to the acceleration of integration in Europe, the process of reforming the tax structures of the European Union is underway and is aimed to harmonize by means of developing joint efficient tax mechanisms, which to some extent have to compensate for the abolition of trade barriers within the EU. At the same time the Russian government is taking measures to enhance the economic union of the Russian Federation and the development of relations with the countries of the former CIS. The use of tax instruments is becoming an important tool in the optimization of tax structures.

In the context of globalization, where the problem of choosing the rational tax mechanisms regulating the economy remains unsolved and relevant, the need for further reform of the tax regulation is of particular importance.

\section{The Main Part}

In the context of growing international economic integration, the harmonization of the main indicators of the tax system is to unify the structures and principles of taxation, the overall direction of tax reform, tax policy and the harmonization of national tax laws of different states. The trend towards tax harmonization has its objective market conditions due to 
qualitative changes in the global economy, namely the globalization of international economic relations. According to Mason, R., increased mobility of production factors and the internationalization of production and management of corporations lead to blurring of the boundaries between individual countries and the emergence of global markets for goods, services, and capital (Mason, 2011). It is obvious that due to the development of these processes, the regulation of taxation actually moves to the supranational level. Empirical evidence of this impact of globalization on taxation is the convergence of tax systems, as expressed in the approximation of the levels of taxation in the economies of individual countries.

Value-added tax has been changed almost in all countries that joined the EU. The rate of VAT varies according to the list of already existing taxes. Tables 1 and 2 provide information on the EU-27: year of VAT introduction, initial rate, current rate.

Table 1. Introduction of VAT rates in European Union countries (Government finance statistics, 2013; Kireeva, 2012)

\begin{tabular}{ccc}
\hline Country & Year of introduction & Standard initial rate, $\%$ \\
\hline Austria & 1973 & 16 \\
Belgium & 1971 & 18 \\
Bulgaria & 1994 & 18 \\
United Kingdom & 1973 & 10 \\
Hungary & 1988 & 25 \\
Germany & 1968 & 10 \\
Greece & 1987 & 18 \\
Denmark & 1967 & 10 \\
Ireland & 1972 & 16,37 \\
Spain & 1986 & 12 \\
Italy & 1973 & 12 \\
Cyprus & 1992 & 5 \\
Latvia & 1995 & 18 \\
Lithuania & 1994 & 18 \\
Luxembourg & 1970 & 8 \\
Malta & 1995 & 15 \\
The Netherlands & 1969 & 12 \\
Poland & 1993 & 22 \\
Portugal & 1986 & 16 \\
Romania & 1993 & 18 \\
Slovakia & 1993 & 23 \\
Slovenia & 1999 & 19 \\
Finland & 1994 & 22 \\
France & 1968 & 16,66 \\
Czech Republic & 1993 & 11,11 \\
Sweden & 1969 & 10 \\
Estonia & 1991 & \\
& & \\
\hline
\end{tabular}

Table 1 shows that the highest rate of 25\% was in Hungary, whereas in Cyprus it was only 5\%. By 2012, the standard rate of tax in Slovakia dropped to 20\%, whereas in Cyprus the standard rate rose in 2012 to 20\%. In the UK, the rate has grown from $10 \%$ in 1973 to $20 \%$ by 2012 
Table 2. The current rate of VAT for 2000-2014 (Government finance statistics, 2013; VAT Rates Applied in the Member States of the European Union, 2014)

\begin{tabular}{|c|c|c|c|c|c|c|c|c|}
\hline \multirow[b]{2}{*}{ Country } & \multicolumn{2}{|c|}{2000 г. } & \multicolumn{2}{|c|}{2010 г. } & \multicolumn{2}{|c|}{2012 г. } & \multicolumn{2}{|c|}{2014 г. } \\
\hline & Stand. & $\begin{array}{l}\text { Preferen- } \\
\text { tial }\end{array}$ & Stand. & Preferen-tial & Stand. & Preferen-tial & Stand. & $\begin{array}{l}\text { Preferen- } \\
\text { tial }\end{array}$ \\
\hline Belgium & 21 & $6 / 12$ & 21 & $6 / 12$ & 21 & $6 / 12$ & 21 & $6 / 12$ \\
\hline Bulgaria & 20 & - & 20 & 7 & 20 & 9 & 20 & 9 \\
\hline Czech Republic & 22 & 5 & 20 & 9 & 20 & 14 & 21 & 15 \\
\hline Denmark & 25 & - & 25 & & 25 & & 25 & - \\
\hline Germany & 16 & 7 & 19 & 7 & 19 & 7 & 19 & 7 \\
\hline Estonia & 18 & 5 & 20 & 9 & 20 & 9 & 20 & 9 \\
\hline Ireland & 21 & $12.5 / 4.2$ & 21 & $13.5 / 4.8$ & 23 & $13.5 / 4.8$ & 23 & $13.5 / 9(4.8)$ \\
\hline Greece & 18 & $8 / 4$ & 23 & $5.5 / 11$ & 23 & $6,5 / 13$ & 23 & $6,5 / 13$ \\
\hline Spain & 16 & $7 / 4$ & 18 & $8 / 4$ & 18 & $8 / 4$ & 21 & 10 \\
\hline France & 19.6 & $5.5 / 2.1$ & 19.6 & $5.5 / 2,1$ & 19.6 & $5.5 / 2.1(7)$ & 20 & $5.5 / 2.1(10)$ \\
\hline Italy & 20 & $10 / 4$ & 20 & $10 / 4$ & 21 & $10 / 4$ & 22 & $10 / 4$ \\
\hline Cyprus & 10 & 5 & 21 & $5 / 8$ & 22 & $5 / 8$ & 19 & $5 / 9$ \\
\hline Latvia & 18 & 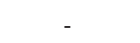 & 21 & 10 & 22 & 12 & 21 & 12 \\
\hline Lithuania & 18 & 5 & 21 & $5 / 9$ & 21 & $5 / 9$ & 21 & $5 / 9$ \\
\hline Luxembourg & 15 & $6 / 12(3)$ & 15 & $6 / 12(3)$ & 15 & $6 / 12(3)$ & 15 & $6 / 12(3)$ \\
\hline Hungary & 25 & $0 / 12$ & 25 & $5 / 18$ & 27 & $5 / 18$ & 27 & $5 / 18$ \\
\hline Malta & 15 & 5 & 18 & 5 & 18 & $5 / 7$ & 18 & $5 / 7$ \\
\hline The Netherlands & 17.5 & $\sigma$ & 19 & 6 & 19 & 6 & 21 & 6 \\
\hline Austria & 20 & 10 & 20 & 10 & 20 & 10 & 20 & 10 \\
\hline Poland & 22 & $7 / 3$ & 22 & $7 / 3$ & 23 & $5 / 8$ & 23 & $5 / 8$ \\
\hline Portugal & 17 & $5 / 12$ & 21 & $6 / 13$ & 23 & $6 / 13$ & 23 & $6 / 13$ \\
\hline Romania & 19 & - & 24 & $5 / 9$ & 24 & $5 / 9$ & 24 & $5 / 9$ \\
\hline Slovenia & 19 & 8 & 20 & 8.5 & 20 & 8.5 & 22 & 9,5 \\
\hline Slovakia & 23 & 10 & 19 & $6 / 10$ & 20 & 10 & 20 & 10 \\
\hline Finland & 22 & $8 / 17$ & 23 & 9/13 & 23 & 9/13 & 24 & $10 / 14$ \\
\hline Sweden & 25 & $6 / 12$ & 25 & $6 / 12$ & 25 & $6 / 12$ & 25 & $6 / 12$ \\
\hline United Kingdom & 17.5 & 5 & 17.5 & 5 & 20 & 5 & 20 & 5 \\
\hline The EU average & 19.2 & & 20.4 & & 21 & & 21.4 & \\
\hline
\end{tabular}

Currently, no country in the EU has elevated rates, although earlier in some countries (about 1991), their level ranged from $22-25 \%$ in France to $38 \%$ in Italy. Reduced rates are available in all countries except Denmark. In all countries, there is also a $0 \%$ rate, except Portugal, where exports are taxed at a rate of $6 \%$. The highest rates today are $27 \%$ in Hungary and 25\% in Sweden and Denmark. The lowest rate is 15\% in Luxembourg, 18\% in Spain and Malta. The average rate for EU countries is $20.7 \%$. Newmark Committee has found that the differences in the overall tax burden can not affect the conditions of competition within the Community. In contrast, differences in tax bases and tax structures have such an effect. Thus, harmonization in the field of direct taxation is a consistent and logical step in relation to the following:

- Taxes on income of companies subject to a "two-tier method" or "method of the separate rate" taxation of distributed and retained earnings as a result of which the corporation tax is partially compensated in respect of distributed profits.

- Taxes, having a direct impact on the movement of capital, such as a tax on equity transactions, the tax on interest and dividends.

- An example is the dynamics of gross domestic product from 1995 to 2013, where the loss of revenue in the national budget can be observed. As long as countries participated in the EU economy VAT rate was forced to change, causing significant damage to the established economy. The initial goal of tax harmonization is to eliminate all tax barriers to the movement of capital in order to create a single market and increase investment.

- Tax harmonization brings the following benefits to the countries involved in the process of economic integration:

- minimizes the adverse effects, which are the result of differences in the tax systems;

- limits the distortion of competition in the commodity and financial markets, creates more favorable conditions for the economically efficient allocation of production factors and optimization of cross-country movement of goods and services, labor and capital; 
- helps to prevent undesirable cross-country tax competition;

- is needed to remove internal customs controls and promotes the development of cross-country trade and economic relations among the countries participating in this process.

The main risk of tax harmonization for the states participating in integration is due to the fact that in the case of its implementation, they lose the right to establish or preserve their tax treatment and tax rates. When tax harmonization is at a too low level, the state may not be able to properly fund its spending, which has a negative impact on the state of the national economy. The country may also lose the ability to impose taxes, which are needed for its political or social standing.

The mechanism of tax harmonization can be described as a complex process, which includes a variety of elements that affect the final result of all delivered events. (Fig.1)

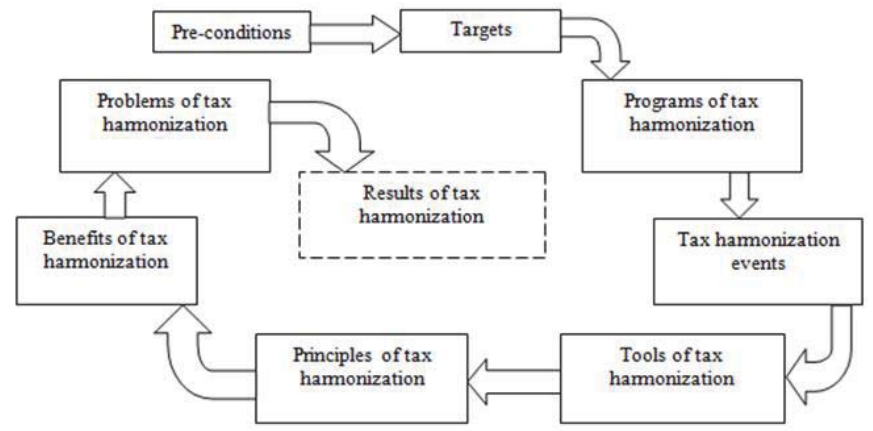

Fig. 1. Mechanism of tax harmonization

Thus, we say that the harmonization of taxation can be characterized as "market tax harmonization", as it is viewed as a reaction to the ongoing globalization of cross-country economic relations and reflects the ongoing process of convergence of tax systems of the member states.

Adopting foreign experience, says van Hulten A., the proposal for a cross-country union for the former CIS countries and the Russian Federation would be appropriate (van Hulten, 2012). This integration grouping will be based on the signing of the accession treaty to the Customs Union. Currently, the customs union comprises three countries Russia, Belarus and Kazakhstan. Interaction in the form of integration association in our opinion should be implemented in phases. The first and one of the fundamental steps should be tax harmonization in the member states, leading to a unified tax system. In the context of this stage, it is particularly important to apply uniform rates for indirect taxation, as only indirect taxes can be imposed at the same rate.

One of the taxes playing an important role in the composition of budgets tax revenue is a value-added tax (VAT). The specifics of the national economies in the structural and sectoral context is quite clearly seen in the structure of the national tax systems (Table 3).

Table 3. The structure of tax revenues by the main types of tax payments of the Customs Union,\%

\begin{tabular}{lcccc}
\hline Tax type & $\begin{array}{c}\text { Tax } \\
\text { revenue }\end{array}$ & $\begin{array}{c}\text { The Republic of Belarus } \\
\text { Tax revenue + Social } \\
\text { protection fund taxes }\end{array}$ & $\begin{array}{c}\text { The Republic of } \\
\text { Kazakhstan * }\end{array}$ & $\begin{array}{c}\text { The Russian } \\
\text { Federation** }\end{array}$ \\
\hline Value added tax & 36,1 & 25,7 & 21,7 & 15,6 \\
Excise duties & 7,6 & 5,4 & 1,9 & 3,1 \\
Corporate income tax & 11,8 & 8,4 & 26,4 & 9,9 \\
Personal income tax & 12,7 & 9,0 & 9,4 & 9,6 \\
Social protection fund taxes & - & 28,7 & 7,5 & 3,3 \\
Property tax & 3,5 & 2,5 & 2,9 & 22,4 \\
Tax on international trade and & 20,6 & 14,7 & 7,4 & 9,9 \\
foreign operations) & & - & & \\
Proceeds from the use of & - & & & \\
natural resources & *State budget, including National fund & & &
\end{tabular}

In the Customs Union countries the structure of tax systems are substantially different, and in the first place, of course, the distinction is in the income derived from the use of natural resources. In Russia, this is one of the main items of the 
formation of the state budget. Republic of Belarus, unlike its partners exports mainly finished products that make us look for opportunities to improve the tax system and to attract investment within a structural component. One of the problems that affects the activity of mutually beneficial trade relations is the uneven distribution of the tax burden among economic entities.

Different VAT rates in the states - members of the Customs Union are explained primarily by differences in economic systems, as well as by advances in economic reforms. A special feature is the presence of a reduced VAT rate of $10 \%$ in the Republic of Belarus and the Russian Federation for the group of goods of social value.

The result was four scenarios of changes in macroeconomic indicators in relation to the application of uniform VAT rates for the selected countries. The rates have been proposed taking into account the VAT rate in the former CIS countries, i.e. the most common: $18 \%, 12 \%, 20 \%$ and $15 \%$ as an alternative. Each scenario presents the data taking into account a uniform rate for the three selected countries and describes the consequences of the introduction of the proposed rates as well as the relationship of VAT with macroeconomic indicators based on a selected uniform rate. The study was performed with the assumption that other economic indicators do not change.

Table 4. Identification codes (symbols) - macroeconomic indicators.

\begin{tabular}{cl}
\hline Indicators & \\
\hline GDP & Gross domestic product, bln rubles \\
EXP & Volume of export, bln rubles \\
IMP & Volume of import, bln rubles \\
EMP & Employment of population, mln of people \\
TREV & Tax revenue, bln rubles \\
INFL & Inflation, \% \\
VAT & Value added tax collections, bln rubles \\
\hline
\end{tabular}

The matrix of correlation coefficients was constructed to determine which factors are most closely associated with the VAT. Table 5 shows the correlation coefficients for the countries studied. Regression models were constructed based on the matrix of pair correlation coefficients.

Table 5. Summary correlation matrix of 3 countries

\begin{tabular}{|c|c|c|c|}
\hline Indicators & Russia & Kazakhstan & Kyrgyzstan \\
\hline \multicolumn{4}{|c|}{ VAT 18\% } \\
\hline GDP & $-0,1427$ & $-0,3370$ & 0,0082 \\
\hline EXP & 0,5116 & 0,1425 & 0,3690 \\
\hline IMP & 0,5065 & 0,6449 & 0,3881 \\
\hline EMP & 0,5162 & 0,9185 & 0,9657 \\
\hline TREV & 0,7958 & 0,9735 & 0,9467 \\
\hline INFL & $-0,8341$ & 0,5917 & $-0,0771$ \\
\hline \multicolumn{4}{|c|}{ VAT $12 \%$} \\
\hline GDP & $-0,2885$ & $-0,3368$ & 0,0077 \\
\hline EXP & 0,5343 & 0,1469 & 0,3749 \\
\hline IMP & 0,5352 & 0,6480 & 0,3685 \\
\hline EMP & 0,5616 & 0,9295 & 0,9657 \\
\hline TREV & 0,7975 & 0,9712 & 0,9774 \\
\hline INFL & $-0,8659$ & 0,6057 & $-0,0776$ \\
\hline \multicolumn{4}{|c|}{ VAT $20 \%$} \\
\hline GDP & $-0,1353$ & $-0,3368$ & $-0,0106$ \\
\hline EXP & 0,5505 & 0,1466 & 0,3585 \\
\hline IMP & 0,5431 & 0,648 & 0,3705 \\
\hline EMP & 0,5691 & 0,9295 & 0,19656 \\
\hline TREV & 0,8251 & 0,9712 & 0,9466 \\
\hline INFL & $-0,8399$ & 0,6058 & $-0,0871$ \\
\hline \multicolumn{4}{|c|}{ VAT $15 \%$} \\
\hline GDP & $-0,1427$ & $-0,3368$ & 0,0082 \\
\hline EXP & 0,5116 & 0,1469 & 0,3695 \\
\hline IMP & 0,5565 & 0,648 & 0,3689 \\
\hline EMP & 0,5162 & 0,9295 & 0,9657 \\
\hline TREV & 0,7958 & 0,9712 & 0,9467 \\
\hline INFL & $-0,8341$ & 0,6057 & $-0,0779$ \\
\hline
\end{tabular}


Applying these rates to Kazakhstan and Kyrgyzstan at the rate of 18\%, 12\%, 20\% the closest direct relationship is observed for such factors as TREV and EMP. Such indicators as IMP and EXP have a direct significant relationship with the test indicator. Indicators INFL (inverse link) and GDP (direct link) have little correlation.

On the basis of these results (in terms of the dynamics since 1999), it is possible to draw conclusions about the impact of rates variations on the main macroeconomic indicators. Applying the 18\% rate in Russia GDP and inflation have 0.24 percentage points decreasing trend: The following indicators have a rising trend: exports - $25.3 \%$, imports $16.4 \%$, employment $-0.4 \%$, tax revenues by 2,8319 bln. rub. For Kazakhstan, the use of $18 \%$ rate will have the following effect: GDP will tend to decline by $0.4 \%$; rising trend will be observed for exports $-2.4 \%$, import - $8.8 \%$, employment $0.18 \%$, inflation $-0,61 \%$ and tax revenues by 2,7799 bln. tenge. Considering the application of the same rate to Kyrgyzstan, the following dynamics can be identified: GDP and employment remain unchanged, such indicators as exports, imports and tax revenues have a slight increase: $0.17 \% ; 0.28 \%$ and $1.6033 \mathrm{bln}$. som respectively. The only indicator that has a decline of $0.01 \%$, which is negligible, is inflation.

Applying the $20 \%$ one can identify the following dynamics of macroeconomic indicators in the Russian Federation. A decreasing trend will be observed for GDP - by 0.2 percentage points and inflation by 2.12 percentage points The following indicators have a rising trend: export $-23.89 \%$, imports - $15.42 \%$, employment $-0.41 \%$ tax revenues by 2,5775 bln. rub. For Kazakhstan, the use of $20 \%$ rate will affect the following indicators: GDP will tend to decline by $0.36 \%$, a rising trend will be observed for exports $-2.19 \%$, import $-7.9 \%$, employment $-0.16 \%$ inflation - $0,55 \%$ and tax revenues by 2,5022 bln. tenge. Considering the application of the same rate to Kyrgyzstan, the following dynamics can be identified. GDP and employment remain unchanged, and such indicators as exports, imports and tax revenues have a slight increase: $0.15 \% ; 0.26 \%$ and 1.4466 bln som respectively. The only indicator that has a decline of $0.01 \%$, which is negligible, is inflation.

Given the behavior of macroeconomic indicators, described above, it can be concluded that applying the rate of $20 \%$, the economies of all three countries are subject to major changes that can cause negative economic impact, as well as the rate of $18 \%$ in Kazakhstan and Kyrgyzstan. On this basis, the optimal rate of VAT will be the rate ranging from $12 \%$ to $18 \%$. Thus an alternative rate of $15 \%$ is proposed.

Applying the $15 \%$ rate one can identify the following dynamics of macroeconomic indicators in the Russian Federation. A decreasing trend will be observed for GDP by 0.29 percentage points and inflation by 2.88 percentage points The following indicators have a rising trend: export - 30.35\%, imports - $19.66 \%$, employment $-0.5 \%$, and the tax revenues by $3,3983 \mathrm{bln}$. rub. For Kazakhstan, the use of $15 \%$ rate will affect the following indicators: GDP will tend to decline by $0.49 \%$, a rising trend will be observed for exports $-2.92 \%$, imports $-10.53 \%$, employment $-0.21 \%$, inflation $0.74 \%$ and tax revenues by 3,3363 bln. tenge. Applying this rate in Kyrgyzstan, the indicators are subject to the smallest changes. GDP and employment remain unchanged, and such indicators as exports, imports and tax revenues have a slight increase: $0.21 \% ; 0.34 \%$ and 1,9249 bln. som respectively. The only indicator that has a decline of $0.01 \%$, which is negligible, is inflation.

In our opinion, taking into account the dynamics of the four scenarios the use 15\% VAT rate for the three countries looks rational. The chosen rate is optimal for economic development in the countries studied, and the effects of the transition to it will be the least painful, as a compromise solution to the three selected countries. The use of such a rate opens up the possibility of joining the union by former CIS countries and Russia, many countries with the lagging economy (as shown by the example of Kyrgyzstan), as well advanced countries, thus increasing competition of the Union. Applying the rate of $15 \%$, a gradual transition to a unified tax system for Russia and former CIS countries becomes smoother, simplifying further actions on tax harmonization.

\section{Conclusion}

With globalization, the transformation of taxation occurs in view of the specific nature of the countries integrating into the global economy. Open and topical issue is the choice of rational tax mechanisms to regulate the economy through further reform of the tax regulation. Through tax regulations the state may affect the level and the rate of inflation, stimulate the development of innovative processes, regulate supply and demand, adjust the level of economic development of individual regions of the country, etc. In practice, the tax regulation is achieved by the use of special tools. Tools of tax regulation can be stimulating and constrain, strategic and short-term, economic and socio-oriented.

Four scenarios of changes in macroeconomic indicators in relation to the application of uniform rates of VAT for the selected countries were developed based on the multifactor model, relied on the analysis of the possible use of a uniform VAT rate, as a first step towards tax harmonization within the Union including countries of the former CIS countries and the Russian Federation. Rates have been proposed taking into account the rate of VAT applicable in the territory of the 
former CIS countries, i.e. the most common: $18 \%, 12 \%, 20 \%$ and $15 \%$ as an alternative. Each scenario presents the data, taking into account a uniform rate for the three selected countries and describes the consequences of the introduction of the proposed rates, the relationship of VAT with macroeconomic indicators based on a selected uniform rate.

Based on the analysis of the functioning of national tax systems and built-in mechanisms for tax regulation, the practice of creating and developing a uniform system of tax regulations in the existing cross-country alliances, a theoretical step-by-step model for bilding a unified cross-country system of tax regulation is proposed. The factors influencing interstate tax regulation are identified and systematized

The main purpose of the development and further implementation of the proposed model is to provide a mechanism of tax regulation, which would be aimed at the elimination of tax barriers, optimization of taxes, strengthening tax audit on the basis of an integrated information system of taxpayers in the partner- countries, increased foreign and domestic tax competition under globalization.

\section{References}

Kireeva, E.F., 2012. Tax policy of European Union members and Customs Union members. Problems of competitiveness and harmonization. Belarus Economic Journal, 4: 57-73.

Kuptsova, Yu..V., 2004. Tax policy as an instrument of integration in the European Union. Unpublished dissertation in partial fulfilment of the requirements for the degree of Candidate of Economic Sciences, Plekhanov Russian University of Economics, Moscow, Russian Federation.

Bespalov, M.V., 2009 State tax policy in the current economic crisis. Taxes Magazine, 5: 2-5.

Shapovalov, A., V. Oglih, 2013. Tax policy as one of instruments of innovative development of macroeconomic system. World Applied Sciences Journal, 23 (6): 840-844. DOI: 10.5829/idosi.wasj.2013.23.06.2818.

Boiko, M.A., 2013. Fiscal policy effects on economic growth. World Applied Sciences Journal, 22 (7): $964-968$. DOI: 10.5829/idosi.wasj.2013.22.07.3000.

Atesagaoglu, O.E., 2012. Taxes, regulations and the corporate debt market. International Economic Review, 53 (3): 979-1004. DOI: 10.1111/j.1468-2354.2012.00708.x.

Mason, R., 2011. Federalism and the taxing power. California Law Review, 99 (4): 975-1036.

van Hulten, A., 2012. Remapping the Fiscal State After the Global Financial Crisis. Economic Geography, 88 (3): $231-253$. DOI: 10.1111/j.1944-8287.2012.01152.x

Baistrocchi, E.A., 2013. The international tax regime and the BRIC world: Elements for a theory. Oxford Journal of Legal Studies, 33 (4): 733-766. DOI: $10.1093 /$ ojls/gqt012

De Mello, L., 2013. What can fiscal policy do in the current recession A review of recent literature and policyoptions. Hacienda Publica Espanola, 204 (1): 113-139.

Kharisova F.I. and Rakhmanova I.I. Sampling in Tax Audit. World Applied Sciences Journal 31 (1): 138-142, 2014.

Orlova M.E., Khafizova A.R. The tax component of innovative activity assessment in the Russian Federation // Life Sciences Journal, 11 (11), pp. 328-333.

Government finance statistics - Summary tables - 1/2013 - Data 1997-2012. http://epp.eurostat.ec.europa.eu/portal/page/ portal/product_details/publication?p_product_code=KS-EK-13-001 (Accessed on May 27, 2013)

VAT Rates Applied in the Member States of the European Union. Situation at 1'st July 2014. http://ec.europa.eu/taxation_customs /resources/documents/taxation/vat/how_vat_works/rates/vat_rates_en.pdf (Accessed on July 1, 2014)

Official website of the Ministry of Taxes and Duties of the Republic of Belarus. http://www.nalog.gov.by.

The official website of the Federal Treasury of Russia. http://www.roskazna.ru.

The official website of the Ministry of Finance of the Republic of Kazakhstan. Tax Committee.http://www.salyk.kz.

www.eurasiancommission.org.

www.tsouz.ru. consultant.ru 